\title{
Bohaterki, bojowniczki, przegrane? Hiszpańskie narracje o kobietach zaangażowanych w ruchy lewicowe pierwszej potowy $X X$ wieku
}

\author{
Aránzazu Calderón Puerta, Tomasz Żukowski
}

\begin{abstract}
Abstrakt: Hiszpańskie dyskusje ostatnich lat wytworzyły nowe sposoby mówienia o kobietach w II Republice i w czasie wojny domowej. Po pierwsze, podkreślają znaczenie działania kobiet i pokazują, jak aktywność w sferze publicznej zmienia ich aspiracje, rozumienie własnej roli, poczucie wartości, słowem - obraz samych siebie; po drugie, wydobywają niedostrzeganą przez większość lewicowych projektów różnicę między możliwościami upodmiotowienia obywatelki i obywatela z powodu różnicy praktyk dotyczących płci oraz wynikające z tego nierówności i konflikty; po trzecie, opowiadają heroiczną historię emancypacji kobiet wewnątrz ruchów lewicowych, nierzadko wbrew ograniczeniom owych ruchów; po czwarte, sięgają po historie postaci z drugiego planu - kobiet tworzących sieci społeczne, dzięki którym możliwe było działanie lewicowych organizacji. Wszystkie te aspekty zasadniczo zmieniają obraz rewolucji i historii lewicy jako całości. Przedstawione narracje ujawniają tym samym niezauważane dotąd doświadczenia, które mogą okazać się interesujące w polskim kontekście. Hiszpańskie badaczki pokazały zderzenie kobiet walczących o emancypację z modelami płci dominującymi na prawicy i w ruchach lewicowych, uwikłanie rewolucjonistów i rewolucjonistek we wzory gender, wreszcie próby i strategie przezwyciężania patriarchalnych ograniczeń.

Wyrażenia kluczowe: narracje historyczne o lewicy, emancypacja kobiet, II Republika Hiszpańska, hiszpańska wojna domowa (1936-1939), literatura i kino hiszpańskie
\end{abstract}

W tekście Akuszerki transformacji. Stosunek do PRL-u jako element polityki tożsamości polskiego feminizmu Agnieszka Mrozik stwierdza, że „po 1989 roku doszło do radykalnego odcięcia się feministek od socjalistycznego projektu równouprawnienia kobiet" (Mrozik, 2011, s. 146). Ruch kobiecy lat przełomu widział PRL jako czas emancypacji wprowadzanej „odgórnie”, „na siłę” i w gruncie rzeczy „pozornej”, a diagnozę tę rozszerzał na całą lewicę. Zabrakło języka, w którym dałoby się opowiedzieć historię emancypacji kobiet w Polsce Ludowej i we wcześniejszych polskich ruchach lewicowych; narracji, która nie idealizowałaby ich położenia, a jednocześnie pozwoliła dostrzec szanse stwarzane przez lewicowe projekty, aktywność zaangażowanych w nie kobiet, wreszcie faktyczne - choć z dzisiejszego punktu widzenia niewystarczające - procesy emancypacyjne.

Hiszpańskie dyskusje ostatnich lat są próbą znalezienia takiego języka. Powstały nowe sposoby mówienia o kobietach w II Republice, w czasie wojny domowej oraz o uczestniczkach opozycji antyfrankistowskiej po roku 1939. Zarysowano nowy model kulturowej reprezentacji tamtego czasu, wydobywający niezauważane dotąd doświadczenia. Stworzono tym samym sposób widzenia historii, który może okazać się interesujący także w polskim kontekście.

Hiszpańskie badaczki, pisarki i reżyserki (razem z kolegami - mężczyznami) podjęły próbę opisania dążeń emancypacyjnych kobiet w historycznym kontekście, nie pomijając 
patriarchalnych wzorów kultury i ich oddziaływania. Zwróciły się w stronę doświadczeń uczestniczek wydarzeń. Pokazały zderzenie kobiet walczących o emancypację z modelami płci dominującymi na prawicy i w ruchach lewicowych ${ }^{1}$, uwikłanie rewolucjonistów i rewolucjonistek we wzory gender, wreszcie próby i strategie przezwyciężania patriarchalnych ograniczeń.

W efekcie hiszpańskie narracje otwierają cztery połączone ze sobą pola. Po pierwsze, podkreślają znaczenie działania kobiet i pokazują, jak aktywność w sferze publicznej zmienia ich aspiracje, rozumienie własnej roli, poczucie wartości, słowem - obraz samych siebie; po drugie, wydobywają niedostrzeganą przez większość lewicowych projektów różnicę między możliwościami upodmiotowienia obywatelki i obywatela z powodu różnicy praktyk dotyczących płci oraz wynikające z tego doświadczenia, w tym nierówności i konflikty; po trzecie, opowiadają heroiczną historię emancypacji kobiet wewnątrz ruchów lewicowych, nierzadko wbrew ograniczeniom lewicy; po czwarte, sięgają po historie postaci z drugiego planu, kobiet tworzących sieci społeczne, dzięki którym możliwe było działanie lewicowych organizacji. Wszystko to zasadniczo zmienia obraz rewolucji i historii lewicy jako całości.

Analizę narracji o kobietach na lewicy należy zacząć od paradoksu. Jest nim uznanie równości płci za problem polityczny i jednoczesne pomijanie go w praktyce ruchu robotniczego pierwszej połowy XX wieku. Hiszpania nie była wyjątkiem. Okres II Republiki i wojny domowej to czas bezprecedensowej emancypacji kobiet. A jednak - stwierdza Martha Ackelsberg - „płeć znów zamienia się w konstytutywny element tego, co definiuje się jako polityczne. Kobiety jako takie nie mogą stać się bytami politycznymi” (Ackelsberg, 2006, s. 257)2.

„W polityce - pisze $\mathrm{W}$ innym miejscu - uznanie fundamentalnej różnicy między kobietami i mężczyznami służyło zarówno usprawiedliwianiu relatywnej marginalizacji kobiet $\mathrm{w}$ dostępie do władzy politycznej i społecznej, jak i obwinianiu ich za ten stan rzeczy. Związki zawodowe i partie polityczne formułowały swe programy wedle męskich kryteriów. [...] Ponadto miały skłonność do pogardzania działaniami podejmowanymi przez kobiety w obronie interesów własnych lub innych grup, do ośmieszania ich akcji i odmawiania im politycznego znaczenia" (Ackelsberg, 2006, s. 251)3.

Europejska lewica była dzieckiem swoich czasów. Nie potrafiła uwolnić się od stereotypów zakorzenionych w kulturze dominującej. Tym bardziej interesująca okazuje się historia kobiet rozpoczynających działalność polityczną w ówczesnych warunkach i historia narracji nawarstwiających się wokół ich doświadczenia.

1 W Hiszpanii pierwszej połowy XX wieku istniało wiele różnorodnych, odrębnych i nierzadko skonfliktowanych ruchów lewicowych. Obok socjalistów ogromną rolę odgrywali anarchiści oraz działacze komunistyczni.

2 Tłumaczenie cytatów w niniejszym artykule - Autorzy: A.C.P. i T.Ż.

3 Zjawisko to występuje w Polsce do dziś. Por. analizę narracji o strajku w Żyrardowie w 1981 roku (Mrozik, 2011, s. 150). 


\section{„Rojas” (,czerwone”) i „,kobiety publiczne”}

Kobiety takie, jak La Pasionaria ${ }^{4}$ czy uzbrojone milicianas, to ikony wojny domowej i rewolucji w Hiszpanii. „W czasie wojny kobiety stały się widoczne i uzyskały uznanie bez precedensu w dotychczasowej historii - czytamy w katalogu wystawy 100 años en femenino ('Sto lat w rodzaju żeńskim') - Niektóre doszły do odpowiedzialnych politycznie stanowisk, jak anarchistka i członek FAI [Federación Anarquista lbérica] Federica Montseny, pierwsza kobieta sprawująca obowiązki ministra w rządzie Hiszpanii" (100 años en femenino, 2012, s. 44). Ich obecność - niewątpliwe świadectwo emancypacji - uwikłana była mimo wszystko w patriarchalne praktyki. Zdaniem Mary Nash: „propaganda początku wojny, która potrzebowała kobiety wojowniczki, ubranej w błękitny mundur, wzywającej mężczyzn do spełnienia obowiązku i wstąpienia do armii, bardzo szybko ustąpiła miejsca hasłu «mężczyźni na front, kobiety na tyły»" (Nash, 1999, s. 98, cyt. za: Egido León, 2011, s. 50). Wejście w sferę zarezerwowaną dla mężczyzn wiązało się z symbolicznym napiętnowaniem i to przez obie walczące strony. Opinia

„utożsamiała żołnierki, a przez rozszerzenie - w ogóle republikanki, z pejoratywnym znaczeniem wpisanym w wyrażenia «kobieta publiczna», «kobieta korzystająca z życia» ${ }^{5}$. Należy przemyśleć to przeniesienie znaczenia, obecne nawet wewnątrz samego ruchu lewicowego. Za usprawiedliwienie można uznać fakt, że działo się to w społeczeństwie nieprzywykłym do aktywnej obecności kobiet w życiu publicznym. [...] Z pewnością ta negatywna konotacja towarzyszyła republikankom przez całe życie" (Egido León, 2011, ss. 50-55).

Kiedy zakończył się konflikt zbrojny, „ostateczne zniszczenie pokonanych stało się priorytetem [zwycięzców]" - stwierdzają historycy Julián Casanova i Carlos Gil Andrés (Casanova \& Gil Andrés, 2009, s. 232). „Obelżywa etykieta «czerwony» przeszła do okresu powojennego, oznaczając «nie tylko lewicowe sympatie polityczne, tak jak to było dawniej, ale rodzaj 'nieczystości', fakt bycia innym, bycia pariasem»" (Richards, 1999, cyt. za: Casanova \& Gil Andrés, 2009, s. 234).

W przypadku kobiet „przystąpienie do rebelii” okazywało się skandalem znacznie przekraczającym samo polityczne zaangażowanie i otwierało pole fantazjom o wynaturzeniu. Zdaniem Ángelesa Egido było „eufemizmem ukrywającym domniemane zbrodnie, takie jak ubliżanie faszystom, profanowanie zwłok wrogów" (Egido León, 2011, s. 53). Nieczyste i podejrzane stawały się nie tylko kobiety należące do lewicowych organizacji czy milicji, ale wszystkie w jakikolwiek sposób związane z Republiką: na przykład narzeczone, żony, matki, siostry czy po prostu przyjaciółki mężczyzn zaangażowanych po stronie lewicy. Skazywano je także za działalność z okresu Republiki, a więc sprzed wybuchu wojny.

Kobiet z obozu zwyciężonych „należało pilnować, reedukować je i oczyszczać, nawet z użyciem oleju rycynowego, jeśli uznano to za konieczne - komentuje Michael Richards. Golono im głowy [...]. Sekcja kobieca Falangi [Sección Femenina de Falange] i Kościót

\footnotetext{
4 Dolores lbárruri Gómez (1895-1989), legendarna przywódczyni Komunistycznej Partii Hiszpanii, aktywna w czasie II Republiki i wojny domowej. Po zwycięstwie Franco żyła na emigracji w ZSRR.

5 Po hiszpańsku określenia te odnoszą się do prostytutek.
} 
z lubością zajmowały się «czerwonymi» kobietami i kobietami «czerwonych», zamęczając je prawdziwymi symbolami kobiecości reprezentowanymi przez Dziewicę Maryję, Izabelę Katolicką i św. Teresę od Jezusa" (Casanova \& Gil Andrés, 2009, s. 236). Kobiety zaangażowane w ruchy lewicowe seksualizowano, redukując je w ten sposób do roli, w której nie było miejsca na polityczny charakter ich działania. Egido León podkreśla „szczególny charakter represji skierowanych przeciw kobietom karanym przede wszystkim za burzenie porządku społecznego i moralnego, który w swoim mniemaniu przywracali zwycięzcy, w przeciwieństwie do mężczyzn skazywanych w istocie za prowadzoną przez nich walkę polityczną" (Egido León, 2011, s. 54).

\section{Uśpione głosy}

Po upadku dyktatury w 1977 roku wróciła pamięć o kobiecych ikonach rewolucji, ale udział kobiet w zdarzeniach i związane z tym kobiece doświadczenie wciąż pozostawały w cieniu.

Praca nad świadectwami, które tradycyjnie nie mieściły się w ramach „Historii” pisanej wielką literą, wymaga szczególnych narzędzi. Anna Aguado podkreśla znaczenie „studiów nad tożsamościami i działaniami kobiet w kulturach robotniczych”, w których „występowała sytuacja podwójnej niewidzialności kobiet: zarówno z powodu podporządkowania płciowego charakterystycznego także dla klasy robotniczej, jak i z powodu rozpowszechnionego przekonania, że były one «bojownikami drugiej kategorii», co sprawiało, że ich akcje i strategie tradycyjnie ignorowano" (Vega, 2010, s. 12).

Pierwszy krok to udzielenie głosu uczestniczkom wydarzeń. Badaczki historii kobiet na lewicy zbierają ich opowieści. Z ich wspomnień zbudowany jest film Mujeres en pie de guerra ('Kobiety na stopie wojennej'; 2004) w reżyserii Susany Koski, do wywiadów nawiązuje także książka Pioneras y revolucionarias. Mujeres libertarias durante la República, la Guerra Civil y el Franquismo ('Pionierki i rewolucjonistki. Anarchistki w czasie Republiki, wojny domowej i frankizmu') Eulàlii Vegi (Vega, 2010) oraz książka Marthy Ackelsberg Free Women of Spain. Anarchism and the Struggle for the Emancipation of Women ('Wolne Kobiety Hiszpanii. Anarchizm i walka o emancypację kobiet') (Ackelsberg, 1991, 2006). Doświadczeniem kobiet zaangażowanych w ruchy lewicowe interesuje się jednocześnie literatura i film, poszukując charakterystycznych cech ich sytuacji, pytając o ich codzienność w tamtym czasie, zaangażowanie, cele i stawki walki oraz miejsce, które zajmowały w lewicowych formacjach.

„[W]arunkiem rozwoju pamięci bez wykluczenia - pisze Anna Aguado - jest istnienie historii krytycznej; krytycznej z punktu widzenia nauki oraz w perspektywie politycznej, wychodzącej od odzyskania pamięci podporządkowanych innym (subaltern), marginalizowanej i pominiętej, przeciwstawionej «pamięci historycznej» - w oczywisty sposób jedynej, która łatwo zamienia się w narzędzie władzy. Pamięć indywidualna i zbiorowa jest bowiem zawsze konstrukcją dyskursywną, składającą się z elementów o naturze symbolicznej" (cyt. za: Vega, 2010, s. 10).

SLH 2/2013 | str. 266 


\title{
I. Historia nauczycielki: kobieta i emancypacja w II Republice
}

Powieść Josefiny Aldecoa to jeden z przykładów krytycznej pamięci. Historia de una maestra ('Historia nauczycielki') jest rodzajem Bildungsroman, choć pisanym à rebours. W klasycznej mieszczańskiej powieści rozwojowej bohater odnajdywał miejsce w społeczeństwie, wykorzystując i spełniając potencjał swojej osobowości. W przypadku bohaterek - szczególnie tych z początków walki o emancypację - to szczęśliwe rozwiązanie okazuje się niemożliwe. Pragnienie wolności i samorealizacji dochodzi do granicy, której nie sposób przekroczyć, ponieważ między poszukującą autonomii kobietą a społeczeństwem, w którym żyje, nie ma harmonii. Wraz ze zdobywaniem samodzielności, bohaterka rozpoznaje raczej siły społeczne, które działają przeciw niej. Aldecoa interesuje się nie tyle pojednaniem, ile rozpoznaniem owych sił, szczególnie tych najmniej widocznych dla szeroko pojmowanej lewicy.

\section{Dziatanie i nowa świadomość kobiet}

Pierwsza część powieści rozpoczyna się w dniu, w którym jej bohaterka, Gabriela, kończy studia: „Koniec etapu i początek marzenia” (Aldecoa, 1996, s. 14). Pisarka śledzi losy dziewczyny należącej do pierwszego pokolenia kobiet, które zdobyły wyższe wykształcenie, weszły w sferę publiczną i zaczęły pracować w zawodach o pewnym spoŁecznym prestiżu. Będzie jej towarzyszyć aż do wybuchu wojny domowej. Marzenie jest rzeczywiście osią konstrukcyjną tekstu ${ }^{6}$. Ma wiele znaczeń. Chodzi o zniesienie społecznych nierówności, o edukację dla podporządkowanych, o sprawiedliwość, ale i rozwój samej nauczycielki, która wchodzi w świat do niedawna niedostępny dla kobiet, przez co - chcąc nie chcąc - wkracza na teren polityki.

Nowe role oznaczają nowy stosunek do samej siebie. Działanie, samodzielność i związane z tym doświadczenie zmieniają Gabrielę. Równościowe ideały zaszczepione przez ojca budzą w niej potrzebę autonomii, którą przeżywa z entuzjazmem. Postrzega samą siebie jako heroinę, ma poczucie samostanowienia i panowania nad własnym życiem. Działa, jest aktywna i zdecydowana na przygodę. Doświadcza spełnienia:

\begin{abstract}
„Mówiłam sobie: nie może istnieć piękniejsze powołanie. [...] Cud tego zawodu sprawiał, że zaczynałam żyć i czułam się zadowolona mimo śniegu i ciemnej kuchni, mimo tego, że dostawałam mało i sama musiałam dawać dużo. A może właśnie z tego powodu. Młodzieńcza egzaltacja zmieniała mnie i w moich własnych oczach otaczała mnie aura bohaterki" (Aldecoa, 1996, s. 40).
\end{abstract}

Gabriela wie, czego chce dokonać, i rozumie wagę przedsięwzięcia: „W ten sposób dotarłam aż tam, z zaangażowaniem, z pragnieniem działania" (Aldecoa, 1996, s. 21). Jej pierwsze posady to zapadłe wioski w hiszpańskim interiorze, gdzie obecność nauczycielki nie jest życzliwie przyjmowana. Nie brakuje konfliktów.

6 Trzy części powieści zatytułowane są: Początek marzenia, Marzenie i Koniec marzenia. 
Świadomość odmienności w stosunku do konserwatywnego i katolickiego otoczenia łączy się ze świadomością własnej odwagi, a co za tym idzie wartości. „Nie jestem tchórzem, tym mniej wtedy" - tak Gabriela ocenia siebie (Aldecoa, 1996, s. 17). Od początku musi konfrontować się z przeciwnościami, ale rozumie, że jej pasja przygody istotnie różni się od męskiej. „Miałam dwadzieścia cztery lata - mówi o sobie - i pasję przygód. Mężczyzna jest wolny. Ale ja byłam kobietą i ograniczały mnie moja młodość, rodzice, brak pieniędzy, moje czasy" (Aldecoa, 1996, s. 53). Spotyka się z krytyką i presją, bo działa samodzielnie i niezależnie, co w przypadku kobiety wywołuje opór. Mimo wszystko w pierwszej części powieści akcent pada na zdolność przezwyciężania trudności i przekraczania granic.

Każdy samodzielny krok zwiększa aspiracje i daje poczucie otwierających się możliwości. Działanie zmienia działającą kobietę. Gabriela zyskuje kapitał świadomości i pragnień związanych z przekonaniem o własnych prawach. Oczekiwania otoczenia nie są już dla niej oczywistością, podobnie jak presja, którą odczuwa jako zamach na własną autonomię i której się przeciwstawia. Denaturalizacja patriarchalnej normy i związanych z nią ról tworzy nowy stan świadomości. Pozwala przyglądać się sobie i własnemu doświadczeniu, konfrontować marzenie i rzeczywistość, wreszcie dostrzegać spełnienie albo przegraną. Tego rodzaju dystans okaże się niezwykle ważny. Decyduje o tym, jak Gabriela przeżywa i rozumie II Republikę i jak widzi swoje uczestnictwo w wydarzeniach.

\section{Granice możliwego}

W pierwszej części powieści Josefina Aldecoa uwypukla proces wkraczania na coraz to nowe obszary doświadczenia i działania. Jej bohaterka decyduje się na coś więcej niż samodzielna praca na prowincji. Wybiera posadę w kolonii, w Gwinei Równikowej. Dla hiszpańskiej kobiety końca lat dwudziestych XX wieku to zuchwalstwo, które budzi nieufność i protesty otoczenia. Najpierw jeszcze w domu: „Załatwiłam wszystkie formalności, puściłam mimo uszu rady i płacze rodziny, i pojechałam do Kadyksu. [...] Potrzebowałam siły emigrantów i odwagi konkwistadorów" (Aldecoa, 1996, s. 54). W Afryce Gabriela okazuje się outsiderką. Samotna, wykształcona i działająca kobieta to ktoś, kto nie mieści się w przyjętym obrazie ról i stosunków międzyludzkich. Pobyt w Gwinei jest dla niej czasem samotności: „To świat mężczyzn” - konstatuje (Aldecoa, 1996, s. 69).

Afryka - podróż do granic - przynosi szczególnego rodzaju doświadczenie. Gabriela poznaje czarnego lekarza, Emile. Później, w pozbawionym namiętności małżeństwie, powie: „Przygoda w Gwinei. To rzeczywiście mogłaby być droga do wolności” (Aldecoa, 1996, s. 176). Z Emile łączy ją przyjaźń. Powieść nigdzie nie wspomina o romansie, choć otoczenie - seksualizując obcych, Murzyna i samodzielną białą kobietę - dopatruje się

7 „Wtedy wierzyłam bardziej w sprawiedliwość niż w miłosierdzie. Moje marzenia szły gdzie indziej. Edukacja, kultura, "wolność działania, wyboru, decyzji. I przede wszystkim godne warunki życia, jedzenie, higiena, zdrowie" (Aldecoa, 1996, s. 70). 
erotycznego podtekstu ich relacji ${ }^{8}$. Jest publicznie upominana, choć nawet wpływowym osadnikom odpowiada, że „nie mają prawa osądzać, jak się prowadzi” (Aldecoa, 1996, s. 76).

W przyjaźni z Emile i w późniejszym wspomnieniu o niej daje o sobie znać przeczucie wolności tout court. Pragnienia, które przekracza najsilniejsze społeczne tabu, a w dodatku sięga do niedostępnych pokładów osobowości. Gabriela myśli o Emile, przeciwstawiając to wspomnienie małżeństwu zawartemu bardziej z uwagi na pokrewieństwo ideałów niż z namiętności. W tej konfiguracji, w obecnych w niej przemilczeniach i niedopowiedzeniach, przygoda w Gwinei staje się znakiem - zabarwionego erotyzmem - przeczucia czegoś najbardziej własnego, a jednocześnie niedostępnego dla samej bohaterki. Spetnienie okazuje się podwójnie niemożliwe: ze względu na społeczny zakaz i alienację od własnych głębokich pragnień.

Wraz z małżeństwem kończy się entuzjazm Gabrieli, choć wydawałoby się, że wybrała dobrze i świadomie.

„Nigdy nie myślałam, żeby wyjść za mąż dla samego małżeństwa. Ale kiedy poznałam Ezequiela, nagle uświadomiłam sobie, że w końcu czymś normalnym jest wziąć ślub i mieć dziecko. I że przecież nie przeszkodzi mi to w pracy, i że on też jest nauczycielem, i właśnie przez to, przez pokrewieństwa zaangażowania i entuzjazmu wszystko się zaczęło" (Aldecoa, 1996, s. 85).

Chcą z mężem tworzyć parę, w której obie strony mają równe prawa, i z całą pewnością prześcigają pod tym względem swoją epokę. Gabriela nie przestaje pracować. A jednak dają o sobie znać siły, którym nie potrafi się przeciwstawić: „Odkąd wyszłam za mąż, wszystko w moim życiu stało się powagą i pracą [...]. Bardzo zmieniłam się od czasów przygody w Gwinei” (Aldecoa, 1996, s. 124).

\section{Antybohaterka - polityka i dom}

Córka przychodzi na świat w dniu proklamowania II Republiki. Ezequiel przynosi rodzącej żonie wiadomość: „Już jest, Gabriela, już ją mamy!” (Aldecoa, 1996, s. 105). Nie ma na myśli dziecka, ale nowy porządek polityczny. To nieporozumienie jest znakiem rozchodzenia się zbiorowego doświadczenia wybuchu wolności politycznej w kraju z doświadczeniem Gabrieli, która popada w coraz większą alienację. Macierzyństwo staje się najważniejszą sprawą jej życia, ale nie znajduje w nim spełnienia: „Strach [o dziecko A.C.P., T.Ż] był jednocześnie symptomem mojej własnej choroby, nieuleczalnej obsesji macierzyństwa" (Aldecoa, 1996, s. 173).

Aldecoa tworzy antybohaterkę. W czasach działania, heroizmu i rewolucji obserwuje kobietę, która - na przekór własnej przeszłości - zostaje w domu. Przygląda się temu, co czuje, jak doświadcza siebie i rzeczywistości, co myśli, co potrafi dostrzec, a przed

8 Pewnej nocy biały administrator szpitala próbuje zgwałcić Gabrielę. „Jeśli byłaś dobra dla Murzyna - mówi - będziesz dobra i dla mnie..." (Aldecoa, 1996, s. 66). 
jakiego rodzaju wiedzą się broni. Narracja powieści skupia się na pytaniu o przyczyny i mechanizm jej przegranej.

Gabriela i Ezequiel wiele widzą i powinni rozpoznać to, co ich spotyka. A jednak ich świadomość dotyczy innych i na niewiele zdaje się w ich własnym przypadku. W rozmowie o różnicach między uczniami i uczennicami Gabriela zapewnia męża: „Nie są inne [...]. Ale oddychają innym powietrzem. Od kołyski przygotowują je, żeby stały się kobietami uległymi, jak to tylko możliwe. Wstydzą się wtrącać, uważają, że nie będą wiedzieć i nie poradzą sobie..." (Aldecoa, 1996, s. 161). Problem nie leży w wiedzy, lecz w praktyce, w modelu zapisanym w świadomości społecznej i ciałach poszczególnych ludzi (Bourdieu, 2004).

Gabriela wie, co dzieje się między nią a mężem, a jednocześnie nie dopuszcza do siebie tej wiedzy. Marcelina, sąsiadka i przyjaciółka z miasteczka, mówi z wyrzutem: „Przecież pani też dużo pracuje. [...] Czy pani chce, czy nie, uczy pani w szkole, tak jak on. Ale kto gotuje, kto pierze, kto prasuje, kto haruje przy dziecku? A on chodzi tam i z powrotem na rynek albo do kopalni [żeby dyskutować z robotnikami - A.C.P., T.Ż.]” (Aldecoa, 1996, s. 174). Gabriela stara się ją uspokoić. „Rozumiałam ją - wyznaje - na moich kursach dla dorosłych walczyłam z kobietami, żeby wpoić im świadomość ich praw. A teraz czułam się złapana w pułapkę własnych ograniczeń" (Aldecoa, 1996, ss. 174-175).

Podział ról między małżonkami jest do pewnego stopnia negocjowany, ale w dużej mierze pozostaje reprodukowaną nieświadomie oczywistością. Wykształcenie, lewicowe przekonania i doświadczenie niewiele zmieniają. Dla Gabrieli nie ulega wątpliwości, że Ezequiel potrzebuje innych mężczyzn, żeby rozmawiać o polityce. Drogi małżonków coraz bardziej się rozchodzą. On angażuje się w rewolucję, ona pozostaje w domu.

Aldecoa skupia uwagę na Gabrieli, choć obok niej pojawia się para, która nie utraciła entuzjazmu i aktywnie uczestniczy w wydarzeniach. To Inés i Domingo, zaangażowani w strajki górników. „Domingo zjawił się w naszym życiu w momencie, w którym potrzebował tego Ezequiel" - czytamy (Aldecoa, 1996, s. 168). Zaangażowanie w strajki przywraca go do życia. Natomiast Gabriela coraz bardziej wycofuje się i patrzy na wydarzenia $z$ rosnącym strachem. Wreszcie kiedy mąż ginie rozstrzelany po wkroczeniu wojsk Franco na początku wojny domowej, zostaje sama z dzieckiem.

W porównaniu z Inés gospodyni domowa musi wydawać się nieciekawa i przyziemna. Gabriela widzi to, odczuwa niewygodę i ból, dusi się w roli, którą przyszło jej odgrywać. To także jedna z przyczyn powiększającego się dystansu między nią a mężem, który zbliża się do Inés i Dominga. Z punktu widzenia narracji skupienie na Inés, bohaterce par excellence, zaangażowanej i aktywnej, oznaczałoby ucieczkę od problemu. Dla Aldecoa znacznie ciekawsze jest przyglądanie się strukturze, której częścią jest człowiek polityczny, kontekstowi społecznemu, w którym żyje, wreszcie jego płci. Zaangażowanie okazuje się rodzaju męskiego ze względu na przyjmowany jako oczywistość podział ról, który mu towarzyszy. Gabriela tworzy zaplecze walki Ezequiela. Antybohaterka jest cieniem 
heroicznej opowieści, nieodłączną drugą stroną monety. Dba o dom i zostaje z dzieckiem. Gdyby poszła w ślady Inés, inna kobieta musiałaby przejąć tę rolę.

\section{Ślepe plamki lewicowego projektu}

Gabriela zajmuje w modelu rewolucji miejsce niewdzięczne, chociaż nie do pominięcia. Jednocześnie jest to miejsce, z którego widać ograniczenia lewicowego projektu wpojonego jej przez ojca. Aldecoa precyzyjnie je punktuje.

Gabriela tak widzi swoją drogę:

„Wychowana przez rodziców bez religijnych hamulców byłam jednak zależna od przykładu ich zachowania, a to po cichu zaprzeczało wolności, która wydawała się podstawą edukacji, jaką mi dali. Wolność jest w głowie, zwykł mawiać ojciec. To pewne. Ale potężna konstrukcja przyzwyczajeń, opinii, punktów widzenia wznosiła się między tą wolnością a moim sposobem działania. Tak, wolność myślenia. Ale niebezpiecznie jest z powodu tej wolności przekraczać granice odwiecznych tabu, które oddzielają dobro od zła, właściwe od niewłaściwego. Dla moich rodziców niewłaściwe z mojej strony byłoby, gdybym pewnego dnia podała w wątpliwość trwałość mojego małżeństwa. [...] Dobra żona, dobra matka, dobra obywatelka. Pułapka zatrzaskiwała się nade mną" (Aldecoa, 1996, ss. 175-176).

Aldecoa wydobywa przede wszystkim znaczenie praktyk - nieświadomych i niewerbalizowanych - oraz ich skuteczność w podmywaniu i neutralizowaniu egalitarnego projektu. Transgresja, którą była praca w Gwinei, okazuje się stosunkowo łatwym krokiem w porównaniu z przekroczeniem takich tabu, jak zobowiązania żony albo matki. Jest to tym trudniejsze, że kobieta nie może spodziewać się wsparcia ani ze strony rodziców, którzy zaszczepili jej pragnienie wolności, ani ze strony grup politycznych dążących do społecznych reform. Gabriela pozostaje sama. Zestawienie narodzin II Republiki i córki Gabrieli jest pełne goryczy i ironii. Wolność polityczna nie oznacza wolności dla żony i matki. Przeciwnie. Wolny może być obywatel - Ezequiel.

Na poziomie narracji, a więc sposobu kontrastowania zdarzeń i doświadczeń, staje się jasne, że błąd tkwi w rozumieniu wolności, które reprezentuje ojciec Gabrieli. Wolność może być „w głowie” tylko dla mężczyzn, czyli dla tych, którzy w strukturze społeczno-kulturowej obsadzili role heroiczne. Antybohaterka jest tak pogrążona w codzienności i narzucanych przez nią obowiązkach, pracach, których nie sposób zaniedbać, i odpowiedzialności za byt, że wolność myśli staje się dla niej jedynie abstrakcją. Jej praca tworzy podstawy, dzięki którym inni - mężczyźni, ludzie polityczni - mogą pozwolić sobie na przebywanie w sferze wolności myśli. Tyle że z ich perspektywy gospodyni domowa, „dobra obywatelka", zasługuje jedynie na pobłażanie lub pogardę. Wedle hierarchii i ocen formułowanych na politycznej agorze jest nikim i Gabriela dobrze o tym wie.

Egalitarny lewicowy projekt pomija praktyki związane ze sferą reprodukcji życia spoŁecznego w jego najbardziej podstawowych przejawach. Gabriela wielokrotnie powtarza, że nie ma kontaktu z własnym kobiecym erosem. Mimo to chce mieć dziecko. Spełnienie 
tego pragnienia stwarza sytuację, która okazuje się zupełnie inna dla niej i dla jej męża. Jemu nie przeszkadza ani w pracy, ani w działaniu politycznym. Jej udaje się obronić jedynie pracę. Nie przestaje uczyć - są przecież egalitarnym małżeństwem - ale płaci za to wysoką cenę. Szkoła pozostaje enklawą, gdzie czuje się wciąż spełniona, ale w pozostałe sfery życia miesza się obowiązek, surowość i gorycz. O uczestnictwie w polityce nie może być mowy. Tak zrealizowało się marzenie.

\section{Anarchistki: emancypacja kobiet wewnątrz ruchu lewicowego}

Bohaterki filmu Vicente Arandy Libertarias ('Anarchistki'; 1996) zaczynają w miejscu, w którym Gabriela kończy swoją drogę. Szukają sposobu przekroczenia praktyk ograniczających wolność kobiet, zniesienia różnicy statusu i ról między obywatelem i obywatelką, wreszcie przeciwstawiają się dyskryminacji wewnątrz ruchu lewicowego.

Należą do wyjątkowej jak na swoje czasy grupy. Chodzi o wyrosłą z ruchu anarchistycznego organizację kobiecą Mujeres Libres (MM.LL. - 'Wolne Kobiety'). Założono ją w 1936 roku

„jako odpowiedź na potrzeby większości kobiet, które chciały udziału w kulturze i edukacji, ale napotykały tysiące przeszkód wynikających z systemu, który na pierwszym miejscu stawiał potrzeby mężczyzn. Od chwili powstania w 1910 roku CNT [Confederación Nacional del Trabajo - Narodowa Konfederacja Pracy] - anarchistyczny związek zawodowy i jedna z najważniejszych hiszpańskich organizacji robotniczych w pierwszych dekadach XX wieku - przyjmowała kobiety w swoje szeregi i uznawała prawa kobiet. A jednak robiła niewiele lub nic, gdy przychodziło do walki o sprawy dotyczące tylko - albo w pierwszym rzędzie

- kobiet. Dlatego to one same musiały stworzyć osobną i odróżniającą się od reszty ruchu grupę" (Domingo, 2006, s. 67).

Mujeres Libres rozpoczynają walkę o rozwiązanie szczególnego rodzaju problemów związanych z sytuacją kobiet w Hiszpanii. Podejmują sprawę nieodpłatnej pracy kobiet, zakładają i prowadzą ludowe jadłodajnie oraz przedszkola, pomyślane jako instytucje uwalniające kobiety od części obowiązków domowych i przenoszące problem ze sfery prywatnej w społeczną. Zajmują się niezależnością ekonomiczną kobiet w relacjach z partnerami, strukturami rodzinnymi, prostytucją, edukacją seksualną ${ }^{9}$. Główny nurt anarchizmu przyjmowat ten program z rezerwą, choć teoretycznie się z nim zgadzał. Żądania uczestnictwa w ruchu i prawa do organizacyjnej samodzielności kobiet, wynikającej z różnicy ich sytuacji i interesów, okazały się nie do przyjęcia.

CNT i FAI (Federación Anarquista Ibérica - Iberyjska Federacja Anarchistyczna) nigdy nie uznały Mujeres Libres za niezależną organizację.

9 Warto zauważyć, że rozpoznania (i idące za nimi działania) kobiet z hiszpańskiego ruchu anarchistycznego pojawiają się w tym samym czasie co fundamentalne teksty, które wewnątrz ruchu feministycznego pokazują jego ograniczenia i w nowy sposób definiują emancypację. Np. Własny pokój Virginii Woolf ukazuje się w 1929 roku, organizacja Mujeres Libres powstaje w roku 1936. 


\section{Wolne od domu, Kościoła i burdelu}

Film Libertarias zaczyna się od emblematycznej sceny: rewolucjoniści zajmują klasztor i wypędzają mniszki. Chcą spalić budynek. Jedna z zakonnic - o której przełożona mówi, że jest najbardziej niewinna i bezbronna - ucieka przez ogarnięte rozruchami miasto. Próbując ukryć się przed tłumem, wpada do bramy. Szuka mieszkania, gdzie mogłaby liczyć na schronienie i wybiera drzwi, na których wisi medalion z symbolem Serca Jezusowego. Zbieg okoliczności sprawia, że są to drzwi domu publicznego.

Wkrótce do tych samych drzwi zapukają uzbrojone anarchistki. Dom publiczny, podobnie jak klasztor, kończy swoją działalność. Kilka jego dawnych pracownic oraz ukrywająca się tam mniszka zostają przy Mujeres Libres. Widzowie towarzyszą im aż do chwili, kiedy większość zginie w walkach o Saragossę.

Powstaje wspólnota kobiet, które chcą zerwać z tradycyjnymi rolami i już zerwały z symbolizującymi je instytucjami. Mniszka wychodzi z klasztoru zastraszona i pasywna. Przywykła do posłuszeństwa, boi się świata i działania. Nie przeczuwa nawet własnej cielesności ani seksualności. Byłe prostytutki można scharakteryzować w zadziwiająco podobny sposób: posłuszeństwo i podporządkowanie, pasywność. Zamiast „czystości” seksualna dostępność, która ma niewiele wspólnego z kobiecą przyjemnością i zamienia się w wyzysk, nużący i alienujący.

Anarchistki muszą mieć za sobą podobne przeżycia. Dowiadujemy się o nich od Pilar, kobiety zbuntowanej, zdecydowanej i wściekłej, która z doświadczenia zna patriarchalne mechanizmy dyskryminacji i rozumie ich działanie. Na widok obrączki, znaku zaślubin zakonnicy z Chrystusem, Pilar mówi: „Cudownie. Mąż, któremu nie trzeba robić kolacji ani słać łóżka”.

Patriarchalna praktyka, której instrumentami są dom, Kościół i burdel, nie przestaje obowiązywać wraz z wybuchem rewolucji. Przekonała się o tym Gabriela z powieści Josefiny Aldecoa. Bohaterki Libertarias mają własny sposób na zmianę społeczną. Tworzą wspólnotę kobiet, środowisko sprzyjające wolności, eksperymentowaniu z własnym życiem i pragnieniami; dające poczucie zrozumienia, akceptacji i wsparcia, którego nie miała Gabriela; chroniące przed ośmieszeniem i krzywdzącymi ocenami. Grupa anarchistek jest barwna i różnorodna, pełna indywidualności. Od zakonnicy, która poznaje zupełnie nowy dla siebie świat, konfrontuje się z nowymi doświadczeniami i wchodzi w nieznane dotąd relacje, przez byłe prostytutki, robotnice i spirytystkę, po młodą dziewczynę oczytaną w Bakuninie.

W mikroskali tego rodzaju kolektyw sprawdza się, a jego strategia okazuje się skuteczna. Na froncie grupa jako całość i jej członkinie z osobna zaczynają funkcjonować w męskim otoczeniu na nowych zasadach ${ }^{10}$. Zyskują szacunek i zgodę na warunki, które

100 tym, jak trudno było kobietom przełamać stereotypy płci związane ze służbą wojskową, świadczą fragmenty powieści La voz dormida ('Uśpiony głos') Dulce Chacón poświęcone Elvirze, która walczy razem z partyzantami: „Mateo nie podobało się, że kobiety były w górach. [...] Akceptował małego rudzielca, bo dowiodła, że jest odważna jak jej brat i że umie obchodzić się z bronią jak mężczyzna. [...] Ale była kobietą, chociaż wyglądała na chłopca, 
stawiają. Są w stanie jasno mówić, czego chcą i czego doświadczają. Dotyczy to także sfer, w których praktyka bywa najgłębiej wpisana w ciało. Już pod Saragossą do jednej z byłych pracownic domu publicznego, Charo, zaleca się mężczyzna, który do okopów trafił prosto $z$ więzienia i boleśnie doświadcza skutków długotrwałego postu seksualnego. Charo jakiś czas odmawia. W końcu zgadza się, ale otwarcie mówi, że to nie będzie jej przyjemność. Seks okazuje się niemożliwy, bo jednakowo niesatysfakcjonujący dla obu stron. Kobieta wychodzi z roli, a jej partner staje przed nową sytuacją: ma przed sobą kogoś, kto nie chce pozostawać niewidzialny i z kim trzeba się liczyćc ${ }^{11}$.

\section{Zderzenie z lewicą}

W skali makro sytuacja przedstawia się jednak inaczej. Rewolucja jest domeną mężczyzn. Bohaterki filmu uczestniczą w niej z całym przekonaniem, a jednocześnie mają świadomość i poczucie obcości. Kontrast między ich aspiracjami a głównym nurtem lewicy i anarchizmu daje o sobie znać już na początku historii. Muszą w sekrecie przemycać na front broń, bo inaczej zostałaby im odebrana. Są wyraźnie na marginesie, traktowane z pobłażaniem, tolerowane, ale nie uznane. Jeszcze przed wojną Mujeres Libres nazywano z „żartobliwą” intencją Mujeres Liebres (Kobiety Zające, a właściwie Króliczki z konotacją seksualną) (Ackelsberg, 2006, s. 257). Pobłażliwe traktowanie, „żarciki” i seksualizacja są sposobami osadzania kobiet w podrzędnej roli i ignorowania ich głosu. Z podobnego rodzaju traktowaniem, aluzjami i znaczącymi spojrzeniami spotykają się bohaterki filmu.

Kiedy przyjeżdżają do Barcelony, przez uliczne głośniki przemawia José Durrutij ${ }^{12}$. Podniosły styl, którym się posługuje, nie wróży im nic dobrego: „W tych historycznych momentach, w tych decydujących chwilach, umocnieni natchnieniem i entuzjazmem dzielni synowie ludu, którym udało się pokonać wojsko w Barcelonie, są gotowi wyruszyć na Saragossę, na pomoc swym aragońskim braciom”. W patosie heroicznej walki „synów ludu” i „aragońskich braci” nie ma miejsca na Wolne Kobiety. Aranda pokazuje tę sprzeczność i wynikające z niej napięcie. Na ekranie widzimy twarze oddające zaciętą niezgodę słuchających Durrutiego uzbrojonych kobiet.

Do bezpośredniej konfrontacji z głównym nurtem polityki rewolucyjnej dochodzi podczas spotkania w klubie Mujeres Libres. Przemawia nie byle kto, bo sama Federica Montseny, jedna z najważniejszych postaci ruchu anarchistycznego, która próbuje przekonać zgromadzone anarchistki, żeby złożyły broń i zajęły się zadaniami „odpowiedniejszymi” dla kobiet: pracą na tyłach albo opieką nad rannymi. Odpowiada jej ostro Pilar:

a kobiety nie powinny włóczyć się po górach jak dzikie koty” (Chacón, 2002, s. 261). Ten sam Mateo rzuca uwagę, że Elvira będzie dobrą żoną, bo energicznie pierze w rzece swoje ubrania i na pewno będzie je prała także mężowi. W odpowiedzi słyszy: „Naiwny jesteś, jeśli uważasz, że wyjdę za mąż, żeby opierać męża. Kto chce chodzić czysty, niech sam sobie pierze. Nic się nie nauczyłeś za Republiki. Skończyły się czasy panów” (Chacón, 2002, s. 263).

11 Gabriela z powieści Aldecoa nie przekracza tej granicy i nie decyduje się otwarcie powiedzieć otoczeniu o tym, jak odczuwa własne położenie. Nie mówi też mężowi o braku namiętności między nimi.

12 José Buenaventura Durruti był jedną z najsłynniejszych, emblematycznych postaci ruchu anarchistycznego. Zginął w czasie obrony Madrytu w 1936 roku. 
„Macie nas za wariatki, że chcemy walczyć na froncie? Powiem jasno! Słuchaj! Nie rozumiemy, dlaczego rewolucja ma iść na konto tylko połowy ludu. Jesteśmy anarchistkami, ale też kobietami, i chcemy zrobić własną rewolucję. Nie chcemy, żeby oni nam ją zrobili. Nie chcemy, żeby tylko mężczyźni organizowali walkę, bo jeśli na to pozwolimy, będziemy jak zawsze załatwione! Chcemy strzelać, żeby w chwili podziału [władzy] móc domagać się naszej części. [...] Chcemy umierać, ale umierać jak mężczyźni, a nie żyć jak służące".

Anarchistki z Libertarias różnią się od Inés z powieści Aldecoa. Działają w grupie i są świadome własnych celów. Uczestniczą w rewolucji, ale ich rewolucyjność polega także na walce z jej genderowymi „oczywistościami”. Gabriela przekonała się, że rola „dobrej żony, matki i obywatelki" to pułapka. Pilar dobrze wie, że taką drogę proponuje de facto Montseny. Utrzymanie różnicy ról i statusu między obywatelem i obywatelką oznacza, że „będziemy jak zawsze załatwione”. Po jednej stronie heroiczny mężczyzna, żołnierz i obywatel, po drugiej „dobra obywatelka” w domu albo szpitalu, w istocie służąca. „Domagać się naszej części" w chwili podziału władzy - to dla Pilar i jej towarzyszek tyle, co upomnieć się o Gabrielę, czyli zmienić strukturę, która tworzy pułapkę oddzielającą kobiety od polityki, prestiżu, działania, a w końcu od spełnionego życia.

\section{Bohaterki innej heroicznej historii}

Narracja filmu wydobywa sprzeczności między teorią i praktykami lewicy. Rewolucja, która wydała takie postaci, jak Federica Montseny, i w niespotykanym wcześniej stopniu zmieniła sytuację kobiet, ma także patriarchalną i dyskryminacyjną stronę. Aranda śledzi losy kobiet, które działają na granicy możliwej emancypacji, sięgają po to, o czym w latach trzydziestych ledwie daje się pomyśleć.

Z perspektywy zbudowanych $\mathrm{w}$ ten sposób postaci możliwa jest krytyka głównego nurtu rewolucji. Widoczne stają się te elementy patriarchatu, których nie mogą dostrzec jej główni aktorzy. Lewica okazuje się częścią kultury, z której wyrasta i której się przeciwstawia. Aranda wydobywa i dekonstruuje patriarchalne struktury myślenia i praktyki. W zestawieniu z dążeniami bohaterek męski etos i heroiczny styl Durrutiego są już nie do przyjęcia, podobnie jak argumentacja Montseny. Racje rewolucji pozostają jednak w mocy, chociaż opowieść skupia się na jej ograniczeniach, na kroku, którego lewica w przeważającej części nie była w stanie wykonać.

Anarchistki z Mujeres Libres są w ujęciu Arandy bohaterkami heroicznej historii, która zasadniczo różni się od patosu Durrutiego. Nie tylko podmiotem rodzaju żeńskiego. Chodzi o odwagę sięgania poza dostępny ogółowi horyzont; odwagę krytyki i formułowania własnego głosu z pozycji mniejszości wbrew schematom niekwestionowanym we własnym środowisku; o tworzenie strategii autonomicznego działania i oporu bez żadnych istniejących wcześniej wzorów. Aranda dostrzega w tej historii wzniosłość zdobywanej na przekór wszystkiemu wolności. Patos par excellence rewolucyjny, ale jednocześnie zasadniczo różny od tego, co do niedawna dominowało w hiszpańskiej pamięci zbiorowej. 
Bohaterki Libertarias giną w starciu z elitą wojsk Franco. Marokańczycy z wojsk afrykańskich (Ejército de Africa) gwałcą je i zabijają. Ocaleje jedynie Maria, mniszka, którą oszczędzono ze względu na klasztorny medalik. W ostatniej scenie Maria odnajduje w więzieniu Pilar, która umiera z podciętym bagnetem gardłem. Nie może mówić. Jej głos zamilknie na ponad sześćdziesiąt lat. Skazany podwójnie: przez dyktaturę, ale i pamięć lewicy, dla której Mujeres Libres były nieistotnym marginesem. Aż do niedawna.

Na placu pozostaje postać emblematyczna: była zakonnica. Jej losy tworzą oś historii: poznajemy ją w pierwszej scenie i to właśnie jej będzie dane przeżyć opowiedziane w filmie wydarzenia. Jest kimś, dla kogo rewolucja staje się kluczowym doświadczeniem, choć wcale się w nią w pełni nie angażuje, zaledwie nieśmiało rozpoznaje nowe możliwości, obserwuje i niepostrzeżenie dla samej siebie zmienia się. Należy i nie należy do grupy kobiet, z którą przeszła wojnę domową. W finale zostaje rozpoznana przez oficera wojsk Franco jako „katoliczka”, a więc „swoja”. Ten sam oficer wskazuje na ciała anarchistek i rozkazuje żołnierzom: „Sprzątnijcie te śmieci!”.

Maria z pewnością nie stanie się na powrót tą samą osobą, którą była w czasie pobytu w klasztorze. Pozostawiona na ziemi niczyjej - między starym i nowym porządkiem ma przenieść pamięć o towarzyszkach i ich doświadczeniu.

\section{Uśpiony głos: doświadczenie kobiet w opozycji antyfrankistowskiej}

Historie kobiet pozostających na marginesie ruchu lewicowego, niezaangażowanych, choć z różnych powodów związanych z konspiracją antyfrankistowską, zainteresowały pisarkę Dulce Chacón. W powieści La voz dormida ('Uśpiony głos') znalazł się dialog między Paulino, komunistą i bojowcem (w partyzantce znanym jako Chaqueta Negra), i Pepitą, która nie chce mieć nic wspólnego z polityką, ale z partią komunistyczną łączy ją fakt, że jej siostra Hortensja, żona jednego z towarzyszy Paulino, czeka na wyrok śmierci za walkę w milicji w czasie wojny domowej. Paulino oznajmia: „Musisz wiedzieć, że jestem człowiekiem politycznym i nikt nie może zmienić moich zapatrywań. Nikt. To ważniejsze, niż gdybym miał syna, i tak będzie aż umrę, albo aż mnie zabiją, jeśli mają mnie zabić”. Ona także jest tego świadoma: „I kobieta, która chce dzielić twój los, musi się na to zgodzić" - odpowiada (Chacón, 2002, s. 155). Zdawałoby się, że mamy do czynienia z aż nazbyt dobrze znaną historią. Ale to Pepita jest główną postacią powieści Chacón. Paulino tworzy tło.

\section{Niedostrzeżony udział i sieci społeczne}

La voz dormida to mozaika kobiecych postaci bezpośrednio i pośrednio zaangażowanych w działania Komunistycznej Partii Hiszpanii po przegranej w wojnie domowej; suma ich doświadczeń i przeżyć. Akcja rozgrywa się wokół więzienia Ventas w Madrycie, gdzie 
przetrzymywano kobiety oskarżone o „udział w rebelii”, gdzie odbywały się zbiorowe procesy i gdzie przebywali skazani na śmierć.

Autorka tworzy opowieść o konspiracji przeciw Franco widzianej z perspektywy kobiet. W powieści dominuje to, co zwykle nazywane jest zapleczem i co bywa pomijane w narracji historycznej. Bez działalności bohaterek powieści, bezimiennych kobiet, nie byłoby walk partyzanckich, a partia komunistyczna - podobnie jak inne nielegalne organizacje - przestałaby funkcjonować. U Chacón to one posuwają akcję naprzód - zarówno akcję powieści, jak i Historię przez duże „H”.

Jesteśmy wśród postaci, którym blisko do Gabrieli, tyle że akcent pada na znaczenie ich pracy; także na znaczenie sieci społecznych, w których są zanurzone i które tworzą. Opór okazuje się możliwy dzięki więzom, w których polityka albo ideologia nie zawsze odgrywają najważniejszą rolę. Solidarność, wzajemna pomoc, zaangażowanie i poświęcenie wynikają z rodzinnego pokrewieństwa, przyjaźni i miłości; często z odczuwania zobowiązań wobec ludzi, których nadziei oraz zaufania nie chce się zawieść. Nierzadko mieszają się ze strachem osób już uwikłanych w nielegalne działania i starających się ratować skórę $e^{13}$. Poczucie więzi wynikające ze wspólnoty przeżyć - tych jeszcze sprzed proklamowania Republiki, z czasu wojny domowej i represji po przegranej - jest zasadniczym doświadczeniem bohaterek, a jego utrzymanie staje się stawką ich walki. Chcą pozostać razem, uratować przyjaźń i wzajemne zaufanie, co okazuje się dla nich równoznaczne z oporem i odmową poddania się. Doświadczenie to obejmuje zarówno ludzi zaangażowanych w walkę polityczną i świadomych jej celów, jak i tych, dla których polityka wydaje się schodzić na dalszy plan.

Wśród wielu motywacji, jakie znalazły się w polu widzenia Chacón, jest także element, który można nazwać politycznym. W narracji powieściowej ma jednak zawsze charakter osobisty. Przeważająca większość bohaterek powieści La voz dormida to kobiety z nizin społecznych.

„Pewnie, że byliśmy czerwoni, i oczywiście zajęliśmy folwark - mówi jedna z postaci. Mieliśmy dość harowania przy oliwkach. Resztki, które dało się jeszcze znaleźć po zbiorach, zamieniałyśmy na oliwę i tak wszyscy żyliśmy w nędzy za te trochę oliwek, które zostały na ziemi, bo dniówka parobka nic nie znaczyła i nie starczała nawet na utrzymanie" (Chacón, 2002, s. 214) ${ }^{14}$.

Dopiero za tego rodzaju doświadczeniem wyrażanym w konkretny i dosadny sposób kryją się przekonania ogólniejszej natury: pragnienie sprawiedliwego społeczeństwa, równości, zmiany politycznej, wreszcie nienawiść do Kościoła, wojska, właścicieli ziemskich i faszyzmu.

13 Pepitę wyciąga z więzienia lekarz, sympatyk lewicy, u którego jest służącą. Nie chce, żeby w śledztwie zdradziła, co robił w czasie wojny i że niedawno operował rannego partyzanta, dlatego prosi o wstawiennictwo ojca, generała z otoczenia Franco. Ten jest przekonany, że pomaga skompromitowanemu lewicowymi sympatiami synowi ukryć romans.

14 Sytuację społeczną i gospodarczą w Hiszpanii początku XX wieku, w tym warunki życia robotników rolnych, opisują J. Casanova i C. Gil Andrés (Casanova \& Gil Andrés, 2009, ss. 19-29). 


\section{Zwykła kobieta w opozycji}

W powieści Chacón pojawiają się kobiety świadomie zaangażowane w politykę i takie jak Pepita, która w wielką historię wplątała się niejako przypadkiem i niechcący. Pepita chodzi do więzienia Ventas na widzenia z siostrą i przynosi jej wiadomości od męża w partyzantce. W górach okazuje się, że Felipe jest ciężko ranny, więc Pepita pośredniczy w zorganizowaniu operacji. Krok po kroku coraz głębiej wchodzi w działalność ruchu oporu: „Skrzynki z narzędziami stolarskimi spełniały funkcję gołębi pocztowych i Pepita, nie zdając sobie z tego sprawy, stała się jeszcze jednym członkiem nielegalnej partii komunistycznej, chociaż nigdy się do niej nie zapisała" (Chacón, 2002, s. 334).

Reprezentuje jednocześnie najbardziej tradycyjną rolę zarezerwowaną dla kobiet: oczekiwania i wsparcia, niezauważanego wysiłku i oddania. Jest jedną z tych, które czekają na listy z frontu, zawiadomienia o wyrokach, wystają pod murami cmentarzy, gdzie dokonywano egzekucji, żeby być przy umierających najbliższych. La voz dormida zbliża się do ich doświadczenia.

Pepita przeżywa ciągłe napięcie, strach i nieustającą niepewność o los najbliższych, a co za tym idzie, także swój własny. Niemal mdleje z niepokoju, kiedy ma przekazać lekarzowi, Don Fernando, wiadomość od Chaqueta Negra. Ze zdenerwowania nie może spać w przeddzień podróży w góry z przesyłką dla partyzantów. Drżą jej ręce. Panicznie boi się przesłuchania i tortur. Na nią spada też odpowiedzialność za tych, którzy pozostają: ciężar opieki nad osieroconym dzieckiem siostry i wsparcia dla skazanego na wiele lat Paulino. Pepita zostaje z troskami o materialną stronę utrzymania siostrzenicy i wysyłania paczek do więzienia.

Chacón wydobywa wszystkie te elementy - przemilczane tło heroicznej opowieści i pokazuje cenę, jaką przychodzi płacić za odgrywanie tego rodzaju roli. W La voz dormida przeżycia, które były także udziałem Gabrieli z powieści Aldecoa, zostają publicznie uznane za ważne i znaczące dla zbiorowej pamięci. Film Benito Zambrano z 2011 roku, osnuty na motywach La voz dormida (o tym samym tytule), otwiera dedykacja:

„Ten film jest hołdem dla wszystkich kobiet, które płakały w ciszy w bramach i pod murami cmentarzy. Dla kobiet, które poświęciły się więzionym i prześladowanym. Dla wszystkich kobiet, które zginęły na komisariatach, w więzieniach i przed plutonami egzekucyjnymi”.

Uznanie nie może obejść się bez dostrzeżenia odrębności bohaterek takich jak Pepita. W ostrej rozmowie z łączniczką komunistów Pepita wykrzykuje: „Ciągle mówicie «my» i «my», jakbyście byli jakimś osobnym światem. A inni? [...] Ja nie chcę, żeby ci, co im się wydaje, że w zaciśniętą pięść złapali prawdę ${ }^{15}$, mówili mi, co mam robić i dyrygowali moją osobą. [...] Ja jestem z tych «innych»" (Chacón, 2002, s. 235). To votum separatum jest głosem z niedostrzeganego i pomijanego zaplecza. Staje się on zrozumiały w perspektywie doświadczenia Gabrieli. Jest protestem przeciw ograniczającej roli, ale także żądaniem prawa do własnego życia oraz przestrzeni dla własnych potrzeb i pragnień. Pepita

15 W Hiszpanii wzniesiona, zaciśnięta pięść była - i jest - gestem używanym przez wiele ruchów lewicowych. 
domaga się uznania faktu, jakim jest reprodukcja życia i ciągłość istnienia społeczności. Chce prawa do spokojnego zajmowania się wynikającymi stąd codziennymi obowiązkami. Ma dość ponoszenia konsekwencji za nie swoje wybory.

\section{Heroizm i coś jeszcze}

Wśród bohaterek La voz dormida znalazły się kobiety bezpośrednio zaangażowane w komunizm i walkę z reżimem Franco. Przede wszystkim więźniarki Ventas, a wśród nich skazana na śmierć siostra Pepity, Hortensja. Chacón opisuje więzienne strategie oporu, ale w heroicznej opowieści pojawia się nieznany dotąd element. W porządek walki wchodzi coś specyficznie kobiecego, co modyfikuje całą narrację.

Chodzi o cielesność, ale widzianą ze szczególnej perspektywy. Skatologiczne szczegóły więziennego życia, ustęp i menstruacja stanowiące kontekst walki, to - zdawałoby się - nic nowego. Antyheroiczna literatura sięgająca I wojny światowej i nowsza literatura obozowa przyzwyczaiły do tego rodzaju ujęć, choć przeważnie tylko w odniesieniu do mężczyzn. U Chacón kobieca cielesność nabiera znaczenia przez połączenie ze sferą reprodukcji życia, opieki i domu, zwykle wyłączanych z opowieści o walce. Okazuje się przez to czymś więcej niż indywidualnym doświadczeniem.

Jedna z więźniarek, której niewiele brakuje do końca wyroku, przeżywa menopauzę i rozpacza, że nie będzie już mogła być matką. Kiedy męscy bohaterowie, tacy jak Ezequiel, rezygnowali ze spełnienia obok żony i dzieci, uznawali walkę za rzecz ważniejszą od prywatnego szczęścia. W ich wyborze pobrzmiewała jednak spora doza pogardy dla sfery domowej jako mało ważnej i w gruncie rzeczy pośledniej. Opuszczony dom zwykle trwał mimo wszystko i czekał na powrót bojowników, obsługiwany przez kobiety takie, jak Gabriela czy Pepita.

Epizod o więźniarce z menopauzą stwarza nową relację między domem i reprodukcją życia a walką. Zmusza też do innego postrzegania poszczególnych kategorii osób zaangażowanych w konspirację: kobiet i mężczyzn, bojowców i ludzi z drugiego planu. Kiedy opór więźniarek polega na zachowaniu solidarności i wzajemnym wsparciu, kobieta przeżywająca utratę płodności staje w centrum narracji. Chodzi jednak także o coś więcej. Jej strata jest nieodwracalna i dotyka tego, co wedle kulturowych wzorów najbardziej kobiece. W walce - nawet przegranej - męski gender potwierdza się. W przypadku kobiety niezdolność do rodzenia dzieci i założenia domu odcina ją od tradycyjnie najważniejszego wzoru samorealizacji. Zmiana płci bohatera opowieści musi więc oznaczać zmianę stosunku do tego, co domowe i prywatne. Płacąc za wybory polityczne inną cenę i inaczej postrzegając ją w kontekście całego życia, kobiety muszą także inaczej patrzeć na tych - a właściwie na te - które pozostały na marginesie walki. Ich wybór staje się równoprawny, a działanie nie mniej cenne. 
Hortensja, której sąd odroczył wyrok śmierci do chwili rozwiązania, boi się o los dziecka. Idąc na egzekucję, musi się z nim rozstać, a jedyne co jej pozostaje, to starania, żeby córka trafiła do siostry. Dla Hortensji - inaczej niż dla walczących mężczyzn - sieci spoŁeczne poza murami więzienia i oddziałami bojowców to sprawa najwyższej wagi. Nie do pominięcia. Perspektywa kobiet pozwala je dostrzec i docenić; zrozumieć, jak bardzo są potrzebne i jak podstawową rolę pełnią. W doświadczeniu Hortensji Pepita jest jej najważniejszym sojusznikiem. Zajmuje w narracyjnej strukturze zupełnie inną pozycję niż Gabriela w stosunku do Ezequiela w powieści Historia de una maestra.

\section{Opowieść dla córek}

Chacón podkreśla, że jej powieść oparta jest na świadectwach kobiet, na prawdziwych historiach. Kiedy więźniarki w momentach załamania tracą poczucie sensu oporu i samego imperatywu przetrwania, powtarzają, że muszą przeżyć, „żeby opowiedzieć naszą historię" (Chacón, 2002, s. 122).

Przekazanie historii walk kobiet o emancypację społeczną i genderową okazuje się sprawą niezwykłej wagi. Aldecoa kontynuuje powieść Historia de una maestra powieścią Mujeres de negro ('Kobiety w czerni’). Pisze o córce Gabrieli i o tym, jak pamięta ona matkę. W Libertarias o bohaterkach opowie zakonnica Maria. W La voz dormida Hortensja zapisuje swoją historię w niebieskich zeszytach, które włoży przed egzekucją w becik córki.

Pokolenie córek przechowało te świadectwa, chociaż w warunkach dyktatury nie mogło zrobić z nich użytku. Przez pierwsze trzydzieści lat demokracji nie mówiono o wojnie domowej. Obowiązywał „pakt milczenia”, który miał chronić przed odnowieniem konfliktu groźnego dla stabilizacji państwa. Pamięć o kobietach II Republiki i ich losach okazała się ważna dopiero dla pokolenia ich wnuczek. Opowiadają tę historię w całej złożoności. Pokazują szanse emancypacji kobiet, które były zdecydowane walczyć o autonomię. Wreszcie pamiętają o ograniczeniach tego procesu. Mówią o patriarchalnej stronie rewolucji i ruchu lewicowego w latach trzydziestych i o wolności otwierającej się wewnątrz rewolucji i w szeregach lewicy. Na przekór i dzięki nim jednocześnie.

Po siedemdziesięciu latach opowieść o II Republice i wojnie domowej okazuje się krokiem w kierunku historii zintegrowanej ${ }^{16}$ - zintegrowanej historii Hiszpanii, ale także samych ruchów lewicowych. Mniejszość - kobiety zaangażowane w walkę o emancypację społeczną - pojawiają się w niej na nowych zasadach. Uwalniają się spod presji tradycyjnej - także dla lewicy - narracji, która wyznaczała im podrzędne miejsce w obrazie całości wydarzeń i wymuszała podporządkowanie. Łamią podstawową regułę wytwarzania wrażenia jednolitości ruchu, jego bezkonfliktowości oraz wspólnej walki. Wydobywają tematy i doświadczenia stanowiące dotąd tabu, bo pokazujące cienie większościowego

16 Posługujemy się terminem Feliksa Tycha postulującego napisanie zintegrowanej historii Polski, w której znalazłoby się miejsce na doświadczenie i punkt widzenia polskich Żydów jako mniejszości (por. Tych, 1999, s. 144). Postulat ten podjęła Elżbieta Janicka (Janicka, 2008, ss. 251-252), a jego realizacją jest jej książka Festung Warschau (Janic$\mathrm{ka}, 2011)$. 
sposobu myślenia i działania. Kobiety zaczynają mówić o swojej odrębności, o własnych celach nieznajdujących zrozumienia w głównym nurcie polityki, wreszcie o tym, jak rewolucja wyglądała z ich punktu widzenia.

Opowiadanie historii zintegrowanej jest działaniem krytycznym, które zmienia praktyki większości oraz jej rozumienie samej siebie. Poszerza spektrum spraw dających się dostrzec i opisać. W tym sensie podejmuje namysł charakterystyczny dla rewolucji lat trzydziestych. Ówczesna formuła upodmiotowienia i emancypacji była na tyle pojemna, że pozwalała kobietom żądać wolności na mocy rewolucyjnych haseł. Stwarzała mniejszości podstawy do rozpoznania własnej sytuacji oraz żądania zmiany. Tym właśnie różniła się od projektów, które odwołują się do zastanych i niezmiennych tożsamości.

\section{Bibliografia}

100 años en femenino [katalog wystawy]. (2012). Madrid: Acción Cultural Española.

Ackelsberg, M. (1991). Free Women of Spain. Anarchism and the Struggle for the Emancipation of Women (1. wyd.). Bloomington: Indiana University Press.

Ackelsberg, M. (2006). Mujeres Libres. El Anarquismo y la lucha por la emancipación de las mujeres. (A. Ruiz, Tłum.). Barcelona: Virus Ed.

Aldecoa, J. R. (1996). Historia de una maestra. Barcelona: Anagrama.

Bourdieu, P. (2004). Męska dominacja. (L. Kopciewicz, Tłum.). Warszawa: Oficyna Naukowa.

Casanova, J., \& Gil Andrés, C. (2009). Historia de España en el siglo XX. Barcelona: Editorial Ariel.

Chacón, D. (2002). La voz dormida. Madrid: Santillana.

Domingo, C. (2006). Nosotras también hicimos la guerra. Defensoras y sublevadas. Barcelona: Editorial Flor del Viento.

Egido León, Á. (2011). El precio de la militancia femenina: acción política y represión. W Á. Egido León \& A. F. Asperilla (Red.), Ciudadanas, militantes, feministas. Mujer y compromiso político en el siglo XX. Madrid: Editorial Eneida.

Janicka, E. (2008). Mord rytualny z aryjskiego paragrafu. O książce Jana Tomasza Grossa „Strach. Antysemityzm w Polsce tuż po wojnie. Historia moralnej zapaści”. Kultura i Społeczeństwo, 52(2).

Janicka, E. (2011). Festung Warschau. Warszawa: Wydawnictwo Krytyki Politycznej.

Mrozik, A. (2011). Akuszerki transformacji. Stosunek do PRL-u jako element polityki tożsamości polskiego feminizmu. W K. Chmielewska \& G. Wołowiec (Red.), Opowiedzieć PRL. Warszawa: Instytut Badań Literackich PAN.

Nash, M. (1999). Rojas. Las mujeres republicanas en la Guerra Civil. Madrid: Taurus.

Richards, M. (1999). Un tiempo de silencio. La guerra civil y la cultura de la represion en la España de Franco, 1936-1945. Barcelona: Crítica.

Tych, F. (1999). Długi cień Zagłady. Szkice historyczne. Warszawa: Żydowski Instytut Historyczny.

Vega, E. (2010). Pioneras y revolucionarias. Mujeres libertarias durante la República, la Guerra Civil y el Franquismo. Barcelona: Icaria. 


\section{Heroines, fighters or losers? Spanish narrations about women left-wing activists of the first half of the 20th century}

Abstract: The Spanish public discussion of the recent years has given rise to new ways of speaking about women in the times of the Second Republic and the Civil War. First, they emphasise the importance of women's actions and show how women's public activities change their aspirations, the perception of their own role and their self-esteem. In a word, they change the way they perceive themselves. Second, they show how different gender practices cause differences in the empowerment of male and female citizens, and how they give rise to various types of conflicts and inequalities. Third, they tell the heroic story of the emancipation of women in left-wing movements, which often occurred despite the opposition inside these movements. Fourth, they discover stories of women who worked behind the scenes, but nevertheless contributed to the development of social networks, which made the existence of left-wing organisations possible. All these aspects have been altering the image of the revolution and the history of left-wing movements in general. The narrations in question bring to light previously unnoticed experiences, which might turn out to be interesting in the Polish context. The Spanish scholars showed the clash of women fighting for their emancipation and the dominant left-wing and right-wing gender models. They also investigated how gender roles affected male and female revolutionaries, and how they tried to overcome the patriarchal limitations.

Keywords: historical narrations about left-wing movements, emancipation of women, the Second Spanish Republic, the Spanish Civil War (1936-1939), Spanish literature and film 